\title{
The measurement of serum pyridoxal by a microbiological assay using Lactobacillus casei
}

\author{
BARBARA B. ANDERSON, M. BARBARA PEART ${ }^{1}$, AND \\ CATHERINE E. FULFORD-JONES \\ From the Department of Haematology, St Bartholomew's Hospital, London
}

SYNOPSIS A new method has been developed for the assay of serum pyridoxal using L. casei Bound pyridoxal phosphate in serum is converted by acid hydrolysis to pyridoxal for which this organism is specific. This method proved to be considerably more sensitive than othe? methods so far reported in the literature.

Serum pyridoxal concentrations were measured in 151 control subjects aged 17 to 80 years The range of concentrations found was 1.5 to $13.5 \mathrm{ng} / \mathrm{ml}$ which compared well with values obtained by most workers measuring pyridoxal phosphate by enzymatic methods. A markec fall with age was confirmed, and levels in women of childbearing age were lower than in mer⿳亠口冋

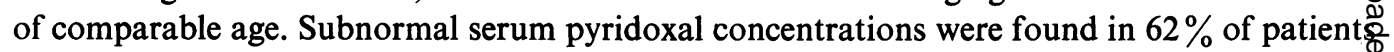
with sideroblastic anaemia and in the majority of patients with rheumatoid arthritis, Crohn' disease, coeliac disease, and in pregnant women at term.

Pyridoxal phosphate is the principal coenzyme form of vitamin $\mathbf{B}_{\mathbf{6}}{ }^{2}$ and is presumably therefore the main $B_{6}$ compound present in the body. There was little definite information about the form of $B_{6}$ in blood until Kelsay, Baysal, and Linkswiler (1968) isolated pyridoxal from acid hydrolysates of whole blood by chromatographic separation and subsequent microbiological assay with Saccharomyces carlsbergensis. Acid hydrolysis converts the phosphate forms of $\mathbf{B}_{6}$ to the free forms, and, as Kelsay et al (1968) could isolate only pyridoxal, it would appear that pyridoxal phosphate is the naturally occurring form of $B_{6}$ in blood. Therefore, the direct measurement of pyridoxal, phosphate or the measurement of pyridoxal after hydrolysis should provide a true assessment of the level of $B_{6}$ in blood.

Several workers have used various enzymatic methods for directly measuring pyridoxal phosphate in whole blood or plasma (Boxer, Pruss, and Goodhart, 1957; Wada, Morisue, Sakamoto, ${ }^{1}$ Present address: Department of Haematology, Royal Prince Alfred Hospital, Sydney, Australia.

'The general term ' $B_{6}$ ' refers to all forms of the vitamin, and is used when no particular form is specified.

Received for publication 27 May 1969. and Ichihara, 1957; Wachstein, Keliner, an Ortiz, 1960; Hamfelt, 1962; Walsh, 1966; Hineso Love, and Peart, 1969). We have measuret. pyridoxal by a microbiological assay methoळ using Lactobacillus casei. A microbiologica承 method deals easily with large numbers of specimens, requires very little serum, and is probably simpler to carry out than enzymati methods. L. casei was chosen as, unlike other microorganisms, it responded only to pyridoxal, and not to the other $B_{6}$ compounds, in the amounts likely to be found in body fluids undet physiological conditions (Snell and Rannefeldo 1945). It was also far more sensitive to $B_{6}$ tham other microbiological or enzymatic methods However, L. casei has appeared in the past to be unsatisfactory for assay of pyridoxal in serump and whole blood because falsely high values were obtained with the prolonged acid hydrolysi\& which was thought to be necessary to liberat pyridoxal (Storvick and Peters, 1964). A possible explanation for this was suggested by Haskell and Wallnöfer (1967) who demonstrated that if serung were acid hydrolysed for longer than two hours $\mathrm{L}$-alanine in serum was converted to D-alanine 


\begin{tabular}{lrcc}
\hline \multirow{2}{*}{ Control Serum } & \multicolumn{3}{c}{ Pyridoxal Concentration $(\mathrm{ng} / \mathrm{ml})$} \\
\cline { 2 - 4 } & \multicolumn{1}{c}{ Range } & Mean & $S D$ \\
\hline A & $0 \cdot 7-2 \cdot 0$ & 1.4 & $0 \cdot 4$ \\
B & $3 \cdot 4-4.9$ & $4 \cdot 2$ & 0.4 \\
C $=$ B $+10 \mathrm{ng} / \mathrm{ml}$ & $12 \cdot 4-16.5$ & $14 \cdot 2$ & 0.9 \\
\hline
\end{tabular}

Table I Summary of 30 consecutive assays on three control sera

\begin{tabular}{|c|c|}
\hline Serum & Pyridoxal Standards \\
\hline $\begin{array}{l}1 \text { Add } 16.5 \mathrm{ml} 0.2 \mathrm{~N} \mathrm{HCl} \text { to universal } \\
\text { container } \\
\text { Add } 0.25 \mathrm{ml} \text { serum }\end{array}$ & \multirow{8}{*}{$\begin{array}{l}\text { Add } 16 \cdot 5 \mathrm{ml} 0.2 \mathrm{~N} \mathrm{HCl} \text { to each of seven } \\
\text { universal containers. } \\
\text { Add } 0,0 \cdot 1,0 \cdot 2,0 \cdot 4,0 \cdot 6,0.8 \text {, and } 1.0 \mathrm{ml} \\
\text { respectively of working solution }{ }^{2} \\
\text { Proceed exactly as for serum. }\end{array}$} \\
\hline cool & \\
\hline $\begin{array}{l}3 \text { Add } 2 \mathrm{ml} 0.5 \mathrm{M} \text { sodium phosphate } \\
\text { buffer } p \mathrm{H} 6.4 \\
\text { Add } 0.5 \mathrm{ml} 8 \mathrm{~N} \mathrm{KOH}\end{array}$ & \\
\hline $\begin{array}{l}4 \text { Check } p \text { H } 6.4 \text { with micro combination } \\
\text { electrode }\end{array}$ & \\
\hline $\begin{array}{l}5 \text { Make volume up to } 20 \mathrm{ml} \text { with distilled } \\
\text { water }\end{array}$ & \\
\hline 6 Steam for three minutes and cool & \\
\hline Thereafter use sterile precautions & \\
\hline $\begin{array}{l}7 \text { Filter through sterile no. } 42 \text { Whatman } \\
\text { filter paper } \\
8 \text { Assay filtrate }\end{array}$ & \\
\hline
\end{tabular}

Table II Preparation of serum and standards by acid hydrolysis

${ }^{1}$ If serum pyridoxal concentration less than $3 \mathrm{ng} / \mathrm{ml}$ use $0.5 \mathrm{ml}$ serum, and if greater than $10 \mathrm{ng} / \mathrm{ml}$ use $0.1 \mathrm{ml}$ or less serum.

'Use pyridoxal $\mathrm{HCl}$ (Sigma) $(121.8 \mathrm{mg}$ equivalent to $100 \mathrm{mg}$ pyridoxal). Two stock solutions, $500 \mu \mathrm{g} / \mathrm{ml}$ and $2.5 \mu \mathrm{g} / \mathrm{ml}$ pyridoxal in $0.02 \mathrm{~N} \mathrm{HCl}$, which may be kept for one year and one month respectively at $4^{\circ} \mathrm{C}$ in dark bottles. Freshly made working solution $5 \mathrm{ng} / \mathrm{ml}$ in distilled water.

\begin{tabular}{|c|c|}
\hline Step No. & Procedure \\
\hline 1 & $\begin{array}{l}\text { Sterilize } 6 \text { in. Pyrex tubes held in aluminium racks and closed with Oxoid } \\
\text { caps }\end{array}$ \\
\hline 2 & $\begin{array}{l}\text { Add } 3 \mathrm{ml} \text { assay medium }{ }^{1} \\
\text { Add } 2 \mathrm{ml} \text { filtrate (serum or standards) in duplicate tubes for each } \\
\text { hydrolysate }\end{array}$ \\
\hline 3 & Inoculate each tube with one drop of inoculum ${ }^{2}$ and shake \\
\hline 4 & Incubate at $37^{\circ} \mathrm{C}$ for 20 hours \\
\hline 5 & Cool tubes at $4^{\circ} \mathrm{C}$ for minimum of $\frac{1}{2}$ hour \\
\hline 6 & Mix contents on Whirlimixer \\
\hline 7 & $\begin{array}{l}\text { Measure growth turbidity in Unicam SP } 1300 \text { colorimeter in a } 1 \mathrm{~cm} \text { cell } \\
\text { using violet filter, Ilford no. } 621(370-515 \mathrm{~m} \mu) \text {, using uninoculated serum } \\
\text { and standard tube contents as blanks respectively. }\end{array}$ \\
\hline 8 & $\begin{array}{l}\text { Plot standard curve on linear graph paper (see Fig. } 2 \mathrm{~A} \text { ) } \\
\text { Final concentration of pyridoxal standards } 0,1,2,4,6,8 \text { and } 10 \mathrm{ng} / 100 \mathrm{ml} \\
\text { Final dilution of serum } 1 \text { in } 200\end{array}$ \\
\hline \multirow[t]{2}{*}{9} & Read serum value from standard curve and multiply by 2 to give $\mathrm{ng} / \mathrm{ml}$ \\
\hline & $\begin{array}{l}\text { Assay sera in two different assay batches and take mean } \\
\text { Run control sera in every batch. }\end{array}$ \\
\hline
\end{tabular}

Table III Assay procedure using sterile precautions for steps $1-4$

'Make double strength medium to $6 / 5$ volume with distilled water and sterilize in bulk at $10 \mathrm{psi}$ for eight minutes (medium autoclaved before dispensing to avoid differences in individual assay tubes due to uneven heating in the autoclave).

${ }^{2}$ (a) Incubate a disc culture of $L$. case $i$ in $10 \mathrm{ml}$ sterile inoculum broth (Difco Bactola ctobacilli broth AOAC-0901-15) at $37^{\circ} \mathrm{C}$ for 16 hours. (b) Transfer $1 \mathrm{ml}$ into $10 \mathrm{ml}$ sterile inoculum broth and incubate at $37^{\circ} \mathrm{C}$ for six to eight hours. (c) Dilute $1 \mathrm{ml}$ in $20 \mathrm{ml}$ sterile single-strength medium for inoculum. and the concentration of this material increased $c$ with length of autoclaving. D-Alanine can $\cong$ replace pyridoxal for growth of $L$. casei (Snell, $\bar{J}$ 1945), and this almost certainly explains the falsely high values obtained.

The purpose of the work described in this paper was to investigate the use of $L$. casei as an assay $\overrightarrow{\vec{F}}$ organism for pyridoxal in serum, and in particular $\overrightarrow{0}$ to study whether a full extraction of pyridoxal 등 from serum could be obtained by acid hydrolysing $\frac{\overline{\bar{\rho}}}{\bar{\sigma}}$ for a shorter period and hence preventing the $\overparen{\nabla}$ production of D-alanine. In view of the importance of alanine in the function of $B_{6}$ in lactic acid ${ }^{\infty}$ organisms (Snell, 1945), the effect on growth of $\vec{\circ}$ the addition to the assay medium of the different $\overrightarrow{\vec{\omega}}$ forms of alanine was studied.

As a result of these studies a specific, sensitive and accurate assay for serum pyridoxal was developed using $L$. casei. This enabled us to measure accurately the serum pyridoxal con- $\omega$ centrations in control subjects and in patients $\omega_{N}^{N}$ with different diseases. Preliminary results are 을 reported.

\section{Materials and Methods}

The assay organism used was Lactobacillus casei NCIB 8010 (ATCC 7469). It was maintained as dried gelatin discs (Stamp, 1947; Chanarin, Anderson, and Mollin, 1958). Glass-distilled water produced by the Loughborough all-glass still was used throughout. All glassware and $\bar{\partial}$ pipettes underwent the rigid cleaning procedure necessary for microbiological assay as described by Waters and Mollin (1961).

\section{COLLECTION OF BLOOD SAMPLES}

Disposable syringes and needles were used to collect venous blood from subjects at least two hours after food. The blood was immediately put into a sterile universal container wrapped in silver paper to protect it from light, allowed to clot, and the serum separated in subdued light. The serum was stored protected from light at 0 $-20^{\circ} \mathrm{C}$ until assayed.

\section{CONTROL SERA}

Three control sera with pyridoxal concentrations covering the range found in health and disease were set up in every assay batch. A large amount was collected for each control serum and stored at $-20^{\circ} \mathrm{C}$. in aliquots sufficient for two assays. Details are given in Table I.

\section{METHOD}

Details of the extraction of serum pyridoxal and the assay procedure are given in Tables II and III respectively. As pyridoxal is sensitive to light? 
all procedures were carried out in subdued light, ie, without artificial lighting and screened from direct daylight.

\section{ASSAY MEDIUM}

The composition of the medium used (Table IV) is a modification of that used by Waters and Mollin (1961) to measure serum folate. The

\begin{tabular}{|c|c|}
\hline Reagent & $\begin{array}{l}\text { Concentration } \\
\text { (per litre) }\end{array}$ \\
\hline $\begin{array}{l}\text { Enzymatic casein hydrolysate } \\
\text { Adenine } \\
\text { Guanine } \\
\text { Uracil } \\
\text { Xanthine } \\
\text { L-Asparagine } \\
\text { L-Cysteine hydrochloride } \\
\text { L-Tryptophan } \\
\text { Riboflavin } \\
\text { p-Amino-benzoic acid } \\
\text { Pteroylglutamic acid } \\
\text { Thiamine hydrochloride } \\
\text { Calcium pantothenate } \\
\text { Nicotinic acid } \\
\text { Biotin } \\
\text { D-Glucose } \\
\text { Tween } 80 \text { solution }(0.5 \% \text { ) } \\
\text { Glutathione (reduced) } \\
\mathrm{Salt} \mathrm{solution}^{3} \\
\text { Sodium acetate (anhydrous) } \\
\mathrm{K}_{2} \mathrm{HPO}_{4} \\
\mathrm{KH}_{2} \mathrm{PO} \\
\text { L-a-Alanine }_{4} \\
\text { MnSO,. }{ }_{2} \mathrm{O} \text { (added after } p \mathrm{H} \text { adjusted to } 6.8 \\
\text { with } 8 \mathrm{~N} \mathrm{KOH} \text { or } 6 \mathrm{~N} \mathrm{HCl} \text { ) }\end{array}$ & $\begin{array}{r}200 \mathrm{ml} \\
10 \mathrm{mg} \\
10 \mathrm{mg} \\
10 \mathrm{mg} \\
20 \mathrm{mg} \\
600 \mathrm{mg} \\
500 \mathrm{mg} \\
100 \mathrm{mg} \\
1 \mathrm{mg} \\
2 \mathrm{mg} \\
0 \cdot 02 \mathrm{mg} \\
0.4 \mathrm{mg} \\
0 \cdot 8 \mathrm{mg} \\
0 \cdot 8 \mathrm{mg} \\
0 \cdot 02 \mathrm{mg} \\
40 \mathrm{~g} \\
20 \mathrm{ml} \\
5 \mathrm{mg} \\
10 \mathrm{ml} \\
40 \mathrm{~g} \\
1 \mathrm{~g} \\
1 \mathrm{~g} \\
1 \mathrm{~g} \\
200 \mathrm{mg}\end{array}$ \\
\hline
\end{tabular}

Table IV Double-strength assay medium $(\mathrm{pH} 6 \cdot 8)^{1}$

'The following ingredients were stored as solutions in dark bottles at $4^{\circ} \mathrm{C}$ : (1) adenine, guanine, and uracil, (2) xanthine, (3) asparagine (4) vitamins at $p \mathrm{H} 4 \cdot 5$, (5) $\mathrm{MnSO}_{4} \cdot \mathrm{H}_{2} \mathrm{O}(6)$, salt solution.

${ }^{2}$ Sterile $5 \%$ solution of enzyme-hydrolysed vitamin-free casein (Nutritional Biochemicals Corporation, Cleveland, Ohio, or Calbiochem Ltd, 10 Wyndham Place, London, W1).

${ }^{3}$ One millilitre contains $40 \mathrm{mg} \mathrm{MgSO}_{4} .7 \mathrm{H}_{2} \mathrm{O} ; 2 \mathrm{mg} \mathrm{NaCl} ; 2 \mathrm{mg}$

$\mathrm{FeSO}_{4} .7 \mathrm{H}_{2} \mathrm{O} . \mathrm{H}_{2} \mathrm{O} ; 1.5 \mathrm{mg} \mathrm{MnSO}{ }_{4} . \mathrm{H}_{2} \mathrm{O}$.

modifications were as follows. (1) Pyridoxine was replaced by pteroylglutamic acid. (2) L-tryptophan was added routinely because the amount in different batches of casein hydrolysate varied (Waters, personal communication). (3) L-Alanine was added for reasons given later. This medium contained enzymatic casein hydrolysate, and particular care was taken to test new batches of this, as growth of $L$. casei varied considerably from batch to batch of casein. This variation was particularly noticeable before L-tryptophan and L-alanine were included in the medium. Furthermore, traces of pyridoxal were found in some batches of casein. These were submitted to ultraviolet light for two to three hours to destroy the pyridoxal before the addition to the medium. Because riboflavin is extremely light sensitive the medium was at all times protected from light (Anderson and Cowan, 1968).
Investigations into the Assay Method

The following special aspects of the assay metho $\overline{\overline{\bar{d}}}$ were investigated.

STABILITY OF $L$. case $i$ IN DISC FORM Growth in standards using $L$. casei, which hat been maintained and subcultured into liquif broth for three months, was compared wit growth using a culture from a newly made disc o L. casei, and there was no significant difference In addition, growth in standards using twơ $L$. casei disc cultures, one 11 months and the other 20 months old, was compared with growth using $L$. casei from a newly made disc and agaif there was no significant difference.

\section{ASSAY MEDIUM}

As $B_{6}$ is known to be involved in the metabolisn of alanine in lactic acid organisms (Snell, 1945)응 the effect of adding alanine to the medium was studied.

$D$ - and DL-alanine When $0.2 \mathrm{~g}$ of either form was included in $100 \mathrm{ml}$ of assay medium, there was uniformly high growth of $L$. casei throughout, whether pyridoxal was present or not.

\section{L-alanine}

In striking contrast, when $0 \cdot 2 \mathrm{~g}$ of L-alanineڤ was included in $100 \mathrm{ml}$ of assay medium there was virtually no increase in growth in the absence of pyridoxal. But there was as marked increase in growth when pyridoxal was? present and this increase was proportional tợ. the concentration of pyridoxal (Figure 1). The slight increase in the blank (Fig. 1), where no? pyridoxal was added, was probably due to traces of pyridoxal in the casein hydrolysate in the medium. The same effect was produced with $0.1 \mathrm{~g}$ of L-alanine per $100 \mathrm{ml}$ of medium as with $0 \cdot 2 \mathrm{~g}$, and this amount was added to the medium? in subsequent assays.

It has been found that varying amounts of L-tryptophan in different batches of enzymatic N casein hydrolysate cause varying growth responses of $L$. case $i$ when assaying folate (Waters, personal communication) and this was confirmed when $\omega$ assaying pyridoxal. It seemed probable that variations in the amount of $\mathrm{L}$-alanine provided ${ }_{C}$ L-tryptophan was added to the medium might $\Phi$ also explain variations in batches of casein. + Figure 1 illustrates the effect of the addition of $\underline{T}$ $\mathrm{L}$-alanine to the assay medium on $L$. casei growth $\stackrel{\text { }}{\mathbb{D}}$ in standards using two different batches of casein $\stackrel{\odot}{\square}$ hydrolysate. Casein A had promoted very poor $\varrho$ growth and casein B apparently good growth but when L-alanine was added to the medium the $ᄋ$ growth was markedly increased in both.

It was also observed that the assay values for serum hydrolysates were significantly higher when 


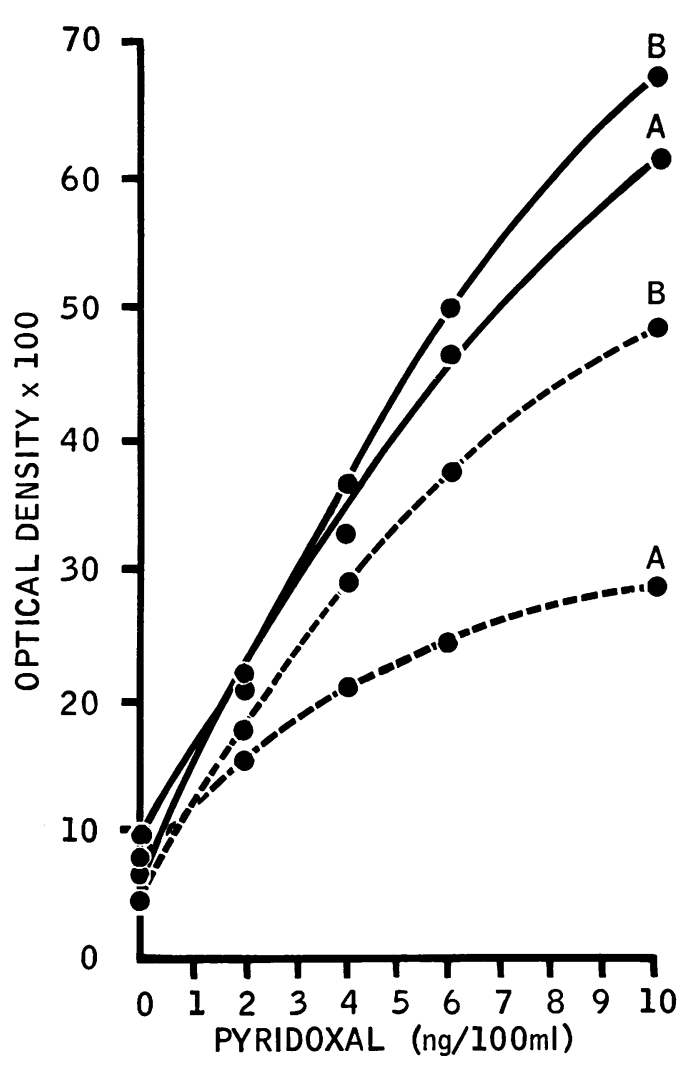

Fig. 1 The effect of the addition of L-alanine to the assay medium on growth of L. casei in pyridoxal standards comparing two enzymatic casein hydrolysates which had promoted $(A)$ poor growth and $(B)$ apparently good growth when L-alanine was not added to the medium.

$\begin{array}{ll}\text { medium. } & \text { No L-alanine in assay medium } \\ \text { L-alanine }(0.2 \mathrm{~g} \text { per } 100 \mathrm{ml}) \text { added to }\end{array}$

L-alanine was not added to the medium, especially when using casein $A$, which was the more deficient in L-alanine (Figure 1). This is probably because some $\mathrm{L}$-alanine is provided by the serum itself and takes effect particularly in sera with high pyridoxal concentrations where growth is high and hence L-alanine in the medium is exhausted. The recovery of pyridoxal added to serum was also falsely high.

\section{Effect of heating}

Equal quantities of medium were autoclaved by steaming for three minutes and at 10 psi for three, eight, and 15 minutes respectively. Growth in these four media decreased with length of heating. Up to eight minutes of heating the curves were parallel, the lowest growth blank being in the latter. The serum values were unaffected. Growth appeared to be depressed when medium was heated for 15 minutes suggesting some destruction of the nutrients. The most suitable length of autoclaving where the growth blank was reduced $c$ was at 10 psi for eight minutes.

\section{PYRIDOXAL STANDARDS}

\section{Effect of storage}

Four separate stock solutions of $500 \mu \mathrm{g} / \mathrm{ml}$ in $0.02 \mathrm{~N} \mathrm{HCl}$ kept at $4^{\circ} \mathrm{C}$ were each tested after 13 , 14,15 , and 16 months respectively and no deterioration was detected as measured by $\widetilde{\Phi}$ growth of L. casei. Similarly, different solutions of $2.5 \mu \mathrm{g} / \mathrm{ml}$ were tested after one, three, and on five months and no deterioration was detected.

\section{Effect of light}

Pyridoxal standards were exposed to ordinary daylight on a dull day for three and a half hours, and, when compared with standards protected from light, more than half the pyridoxal activity as measured by $L$. casei was destroyed.

\section{Effect of heating with assay medium}

Pyridoxal standards were added to the tubes before and after autoclaving with the medium at 10 psi for three minutes. Half the activity of the pyridoxal was destroyed when it was autoclaved together with the medium.

\section{Effect of acid hydrolysis}

Pyridoxal standards were hydrolysed as described in Table II and growth was compared in these standards with aqueous pyridoxal standards, both sets being added after the medium had been sterilized. The growth was higher in the hydrolysed pyridoxal (Fig. 2). This effect was not due to autoclaving. If different concentrations of $\mathrm{HCl}$ were used, the growth increased within limits in proportion to the concentration of $\mathrm{HCl}$ used. However, the precise factor responsible for the increased growth is difficult to assess, because the concentration of $\mathrm{HCl}$ used also determined the amount of $\mathrm{KOH}$ subsequently required to adjust the $p \mathrm{H}$ to $6 \cdot 4$.

\section{SERUM PYRIDOXAL}

\section{Effect of storage}

Serum was stored protected from light and at $-20^{\circ} \mathrm{C}$ for as long as two years and there was no detectable deterioration in the pyridoxal concentration.

Hydrolysates of the control sera were stored as above for several weeks and then assayed together with fresh hydrolysates of the same sera. Hydrolysates which had been stored for up to six weeks showed no significant deterioration but after longer storage the pyridoxal concentration gradually decreased.

\section{Effect of different conditions of hydrolysis}

(1) The concentration of $\mathrm{HCl}$ used was varied 


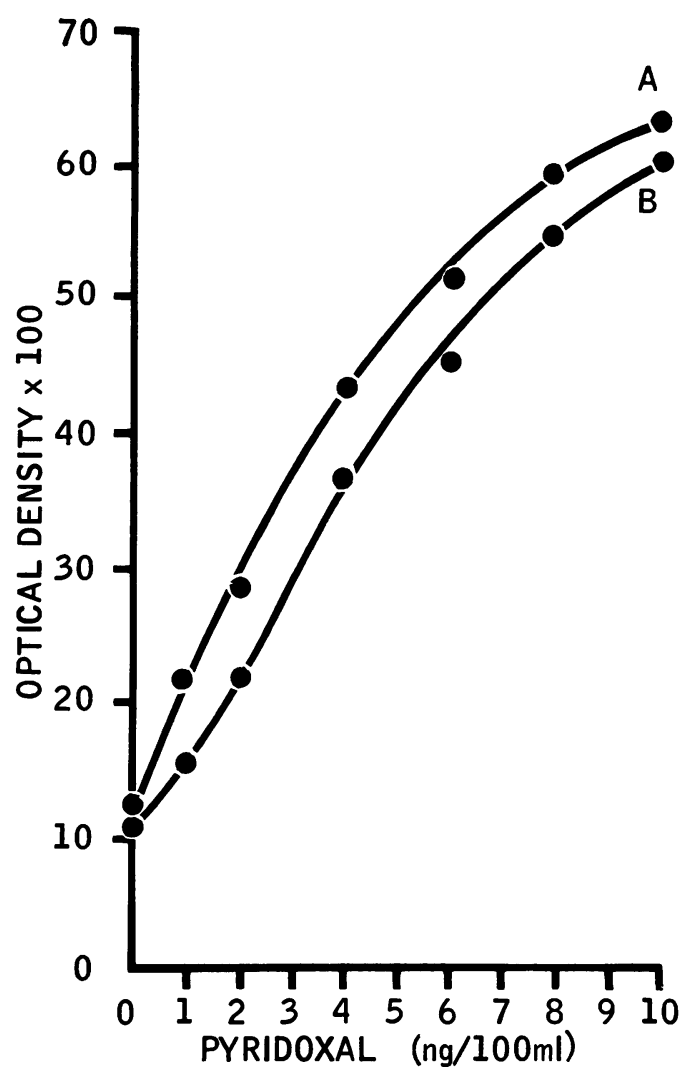

Fig. 2 Comparison of growth of L. casei in $(A)$ pyridoxal standards which had been diluted in $\mathrm{HCl} / \mathrm{KOH}$ mixture as described for preparation of standards (the growth was the same whether hydrolysed or not) and (B) aqueous pyridoxal standards not heated at any stage.

and $0 \cdot 05,0 \cdot 1$, and $0 \cdot 2 \mathrm{~N}$ were compared. (2) The temperature of autoclaving at one hour was varied and pressures of $15 \mathrm{psi}\left(121^{\circ} \mathrm{C}\right)$ and $20 \mathrm{psi}$ $\left(126^{\circ} \mathrm{C}\right)$ were compared. (3) The time of autoclaving at 15 psi was varied and one half, one, and two hours were compared. (4) The final $p \mathrm{H}$ to which the hydrolysate was adjusted was varied,

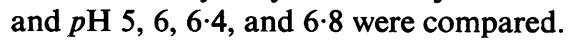

None of these variations had any significant effect on the serum pyridoxal assay value or on the recovery of pyridoxal added to serum, but the effect of the $\mathrm{HCl} / \mathrm{KOH}$ mixture on growth of $L$. case $i$ was the same as for the standards.

\section{Dilution agreement}

Assay values were the same when (1) different amounts of serum were hydrolysed $(0.5 \mathrm{ml}$. and less); (2) different amounts of the hydrolysate were assayed. In view of the growth effect of the $\mathrm{HCl} / \mathrm{KOH}$ mixture used in hydrolysis it was essential that the assay values for serum were read from standards containing the same volume of the $\mathrm{HCl} / \mathrm{KOH}$ mixture.

In practice, the volume of hydrolysate assayed was fixed at $2 \mathrm{ml}$ and the dilution was varied by changing the volume of serum hydrolysed, $\mathrm{eg}_{\Omega}^{c}$ $0.25 \mathrm{ml}$ of serum hydrolysed gives a final dilution of 1 in $200 ; 0.5 \mathrm{ml}$ serum gives a final dilution of 1 in 100 .

IDENTIFICATION OF L.casei GROWTH FACTOR IN SERUM

The assay medium contained no pyridoxal, bu? as far as is known contained all the other factor흔. likely to be found in body fluids, including the other vitamins which were necessary for the growth of $L$. casei. To confirm that the growth factor ire serum hydrolysates was pyridoxal the following experiment was done.

Gel filtration using Sephadex G-10 was carried out on two $5 \mathrm{ml}$ concentrates from pooled? hydrolysates of $2.5 \mathrm{ml}$ of normal serum (1) alone? and (2) with added pyridoxal. Fractions, each of $6 \mathrm{ml}$, were eluted with a $0 \cdot 1 \mathrm{M}$ phosphate bufferic $(p \mathrm{H} \mathrm{6.0)}$. All fractions up to and including the्w last peak of ultraviolet absorbancy at $280 \mathrm{~m} \mu \mathrm{N}$ were assayed with $L$. case $i$.

In the serum hydrolysate with no addedpyridoxal, a small peak of growth was associate with the 'run-through' peak, but most of the growth factor was held on the column and elutedo fairly sharply in the region of substances havingo the molecular weight of pyridoxal (167). In the hydrolysate to which pyridoxal had been added the small 'run-through' peak was slightly in creased, but the rest of the increase in growtho factor for $L$. casei eluted in exactly the same po sition as in the serum sample without addec pyridoxal. This identity of molecular sizeo? determined by gel filtration strongly suggested that the growth factor in serum hydrolysates was $B_{6}$ and hence pyridoxal, being the only formto which $L$. casei responds at these levels. This was further supported by subjecting the peak fractions before assay to ultraviolet light exposure sufficient to destroy $\mathrm{B}_{6}$ and finding that only की very small percentage $(<5 \%)$ of the growth remained in these fractions. It was also shown that the addition of ${ }^{3} \mathrm{H}$ labelled pyridoxine to $\mathrm{a}_{5}$ serum hydrolysate resulted in the appearance op a sharp peak of counts which eluted in the same position as did the growth factor for $L$. casei.

\section{ACCURACY OF METHOD}

Reproducibility and Methods were assayed in 30 consecutives assay batches and during that period four differ $\square$ ent workers carried out the assays. The resultş are summarized in Table I. A serum was extrac $\vec{\Omega}$ ted and assayed 12 times in the same batch andक्षे the reproducibility was good. The range was
$8 \cdot 5-10.4$ (mean 9.5 and $S D \pm 0.6 \mathrm{ng} / \mathrm{ml}$ ).

\section{Recovery of added pyridoxal}

The recovery of pyridoxal added to seruno. $(10 \mathrm{ng} / \mathrm{ml}$ ) ranged from 82 to $120 \%$ (all but five 
The measurement of serum pyridoxal by a microbiological assay using Lactobacillus casei

fell between 90 and $110 \%$ ). The mean recovery was $100 \cdot 1 \%$ and the $\mathrm{SD} \pm 7 \cdot 7 \%$.

\section{RESPONSE OF $L$. case $i$ TO DIFFERENT B 6 COMPOUNDS}

The growth response of $L$. casei to different forms of $\mathbf{B}_{6}$ is summarized in Table V. Pyridoxal was the only compound to which $L$. casei responded at physiological levels. L. casei was about 200 times as sensitive to pyridoxal as to pyridoxamine and was far less sensitive to any other form of $\mathrm{B}_{6}$.

The compounds were acid hydrolysed as described in Table II, and only in the case of pyridoxal-5'-phosphate did this cause an increase in growth response of $L$. casei. In three experiments the recovery of pyridoxal from pyridoxal$5^{\prime}$-phosphate, as measured by growth of $L$. case $i$, was 80,85 , and $95 \%$ respectively.

\begin{tabular}{lll}
\hline & $\begin{array}{l}\text { Aqueous } \\
(\mathrm{ng} / \mathrm{ml})\end{array}$ & $\begin{array}{l}\text { Acid Hydrolysed } \\
(\mathrm{ng} / \mathrm{ml})\end{array}$ \\
\hline Pyridoxal & 0.005 & 0.005 \\
Pyridoxal-5'-phosphate & $5.0^{2}$ & $0.005^{2}$ \\
Pyridoxamine & 1.0 & 1.0 \\
Pyridoxamine-5'-phosphate & 10.0 & 10.0 \\
Pyridoxine & 20.0 & 20.0 \\
\hline
\end{tabular}

Table V An approximate quantitative growth response of $\mathrm{L}$. casei to different forms of $B_{6}$

'The lowest concentration for which $L$. casei shows a measurable growth response.

'In terms of pyridoxal.

Serum Pyridoxal Concentrations in Control Subjects and in Patients with Various Conditions

SUBJECTS STUDIED

Two groups were studied: (1) 151 control subjects ( 75 men and 76 women) aged from 17 to over 60 years. The majority of subjects under 60 years were members of the staff and students. The 54 subjects over 60 years were chosen at random from a national geriatric survey. (2) 134 patients with the following conditions: 26 with sideroblastic anaemia, ie, with ring sideroblasts in the bone marrow and varying degrees of anaemia; 31 with rheumatoid arthritis, many receiving drug therapy; 48 with active Crohn's disease of varying degrees of severity; 16 with coeliac disease of whom four had been on a gluten-free diet; 13 pregnant women near term. These were selected for reasons that will be discussed.

\section{SERUM PYRIDOXAL CONCENTRATIONS IN} CONTROL SUBJECTS

The serum pyridoxal concentrations in 151 control subjects measured by L.casei are shown in Fig. 3, plotted according to age and sex. The mean concentration was calculated in men and women separately in the three age groups 20 to 29,30 to 39 , and 60 years and over. In the other

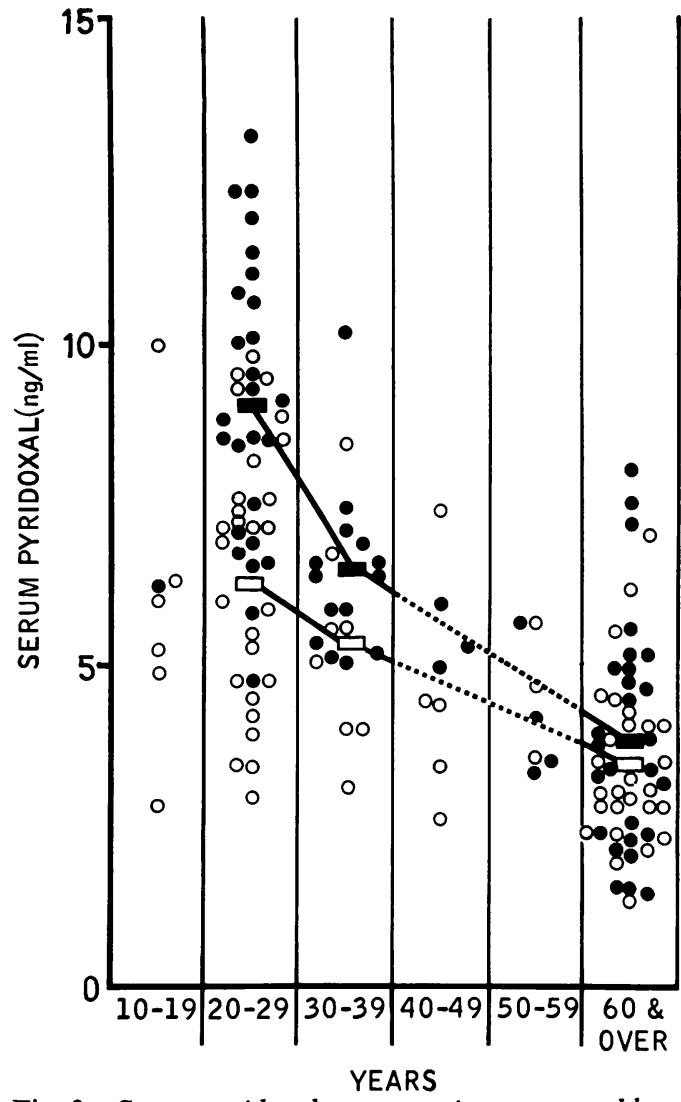

Fig. 3 Serum pyridoxal concentrations measured by L. casei microbiological assay in 151 control subjects. The means for men and women are shown in three age groups where justified by numbers.

$$
\text { - Men } \bigcirc \text { Women }
$$

age groups there were not sufficient subjects to justify calculating the mean.

\section{Sex differences}

The mean serum pyridoxal concentrations were higher in men than in women in the three age groups and the means were as follows: 20 to 29 읙 years 9.1 and $6.5 \mathrm{ng} / \mathrm{ml}$, and the difference was $D$ highly significant $(\mathrm{P}<0.001) ; 30$ to 39 years 6.4 and $5.3 \mathrm{ng} / \mathrm{ml}$, but there were too few $\mathrm{N}$ subjects to prove these significantly different; 60 years and over 3.9 and $3.5 \mathrm{ng} / \mathrm{ml}$, and these $O$ were not significantly different $(0.4>\mathrm{P}>0 \cdot 3)$. $\omega$

\section{Age differences}

There was a steep fall in the mean serum pyridoxal concentrations from the age of 20 to over $60 \stackrel{?}{-}$ years (Fig. 3). The means in the three age groups $\frac{7}{7}$ decreased as follows: men $9 \cdot 1$ to 6.4 to $3.9 \mathrm{ng} / \mathrm{ml}$, $\stackrel{\circ}{\stackrel{\circ}{\circ}}$ and the differences were highly significant $\stackrel{\odot}{\mathcal{P}}$ (P $<0.001)$; women 6.5 to 5.3 to $3.5 \mathrm{ng} / \mathrm{ml}$, and $\unrhd$ the difference between the last two means was statistically significant $(0.01>P>0.001)$.

As there was an approximately even distribution of men and women in all age groups except the first, the mean value was calculated for 


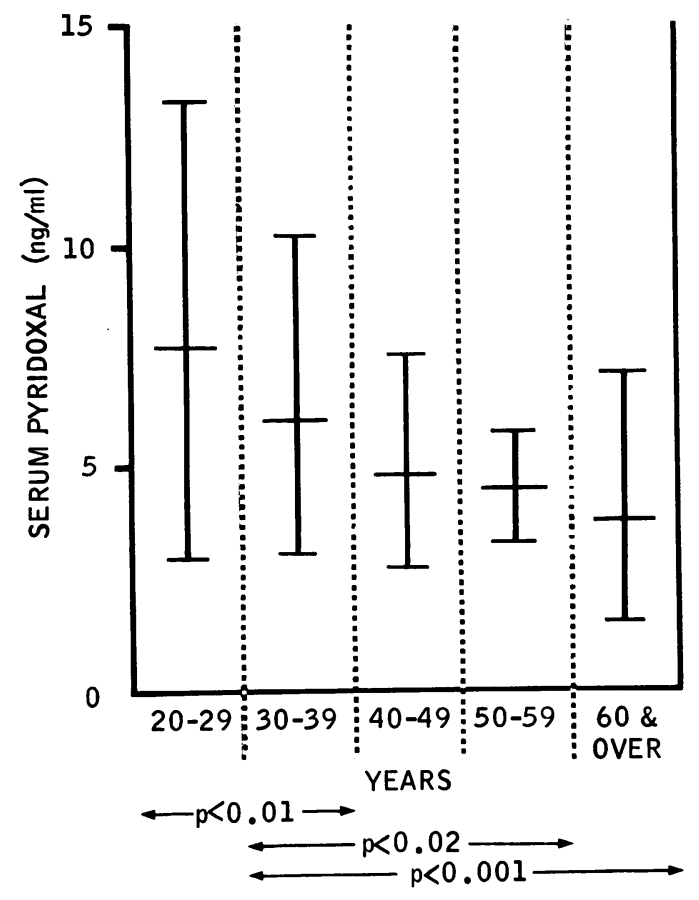

Fig. 4 The ranges and means of serum pyridoxal concentrations in different age groups measured by L. casei in 144 control subjects (74 males, 70 females), together with statistical analysis.

the combined sexes in the other age groups, and once more there was a progressive fall with age (Fig. 4).

COMPARISON OF SERUM PYRIDOXAL WITH PLASMA PYRIDOXAL PHOSPHATE

MEASUREMENTS IN CONTROL SUBJECTS

These results in control subjects are compared with those obtained by another worker (Hamfelt, 1964), who measured plasma pyridoxal phosphate in control subjects using an enzymatic method (Table VI). The means are compared in the age groups which were used by him. His numbers were smaller and he did not take into consideration the sex, but there is a very good agreement between the values by the different methods in each age group.

\begin{tabular}{|c|c|c|c|c|c|}
\hline \multirow[b]{2}{*}{ Measurement } & \multirow[b]{2}{*}{ Method } & \multirow{2}{*}{ Series } & \multicolumn{3}{|c|}{$\begin{array}{l}\text { Pyridoxal Concentration } \\
(\mathrm{ng} / \mathrm{ml})\end{array}$} \\
\hline & & & $\begin{array}{l}20-29 \\
\text { Years }\end{array}$ & $\begin{array}{l}30-59 \\
\text { Years }\end{array}$ & $\begin{array}{l}60 \text { Years } \\
\text { and Over }\end{array}$ \\
\hline Plasma pyridoxal phosphate & Enzymatic & Hamfelt (1964) & $\begin{array}{l}7 \cdot 6 \\
(13)^{1}\end{array}$ & $\begin{array}{l}4 \cdot 8 \\
(11)\end{array}$ & $\begin{array}{l}2 \cdot 3 \\
(21)\end{array}$ \\
\hline Serum pyridoxal & $\begin{array}{l}\text { Microbiological } \\
\text { (L. casei) }\end{array}$ & $\begin{array}{l}\text { Present } \\
\text { authors }\end{array}$ & $\begin{array}{l}7 \cdot 7 \\
(53)\end{array}$ & $\begin{array}{l}5 \cdot 1 \\
(22)\end{array}$ & $\begin{array}{l}3.6 \\
(54)\end{array}$ \\
\hline
\end{tabular}

Table VI Comparison of serum pyridoxal with plasma pyridoxal phosphate measurements in control subjects ${ }^{1}$ The number of subjects studied in each age group.
SERUM PYRIDOXAL CONCENTRATIONS IN PATIENTS WITH VARIOUS CONDITIONS The serum pyridoxal concentrations in various conditions are plotted in relation to age in Fig. 50 where they are compared with the concentrations found in control subjects in corresponding age; groups.

The majority of the patients studied had serum pyridoxal concentrations below the lower limits found in control subjects. In the 26 patients wit sideroblastic anaemia $62 \%$ had subnormal con centrations and $92 \%$ had concentrations beloo

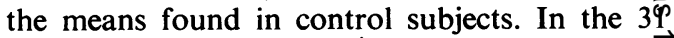
patients with rheumatoid arthritis all but one्e that is $97 \%$, had concentrations which were either borderline or subnormal but mainly well below the control range. In the 48 patients with ung treated active Crohn's disease all but four patients్ that is $92 \%$, had concentrations that were eithers borderline or subnormal, but mainly well below the control range. The former four patients were all older than 50 years. The younger patients, io particular those in the 20-to-29-year group, had consistently very low concentrations and all buts two out of 18 in this group were below $2 \mathrm{ng} / \mathrm{m} \stackrel{\mathrm{m}}{=}$. Twelve of the 16 patients with coeliac disease were untreated and all but two of these patient $\$$ that is $83 \%$, had borderline or subnormal corf centrations, but these were not as consistentl low as in Crohn's disease. The four patients whe had been on a gluten-free diet had concentr㕃 tions well within the control range. In th: pregnant women all 13 had subnormal corf centrations.

\section{Discussion}

ASSAY METHOD

The present observations confirmed those Snell (1945) that D-alanine could replace pyr doxal for growth of $L$. casei when the assay medium contained an enzymatic casein hydro lysate. However, contrary to observations by other workers, the addition of L-alanine to the medium also enhanced growth, but only in this presence of pyridoxal, the increase being in proportion to the pyridoxal concentration. As with Streptococcus faecalis $\mathrm{R}$ therefore, L. cased appears to require $B_{6}$ as the coenzyme for the racemase that converts $L$ - to $D$-alanine, which then becomes available to the organism (Storvicas and Peters, 1964). It is clear that L-alanine is an important ingredient in the assay medium, and variations in the amount of L-alanine in differe batches of enzymatic casein hydrolysate wers responsible for widely different growth responseg. even when adequate amounts of L-tryptophag had been added. No mention has been made previously of the importance of ensuring that the medium contains adequate amounts of L-alanine. and the addition of this has greatly improved tres 


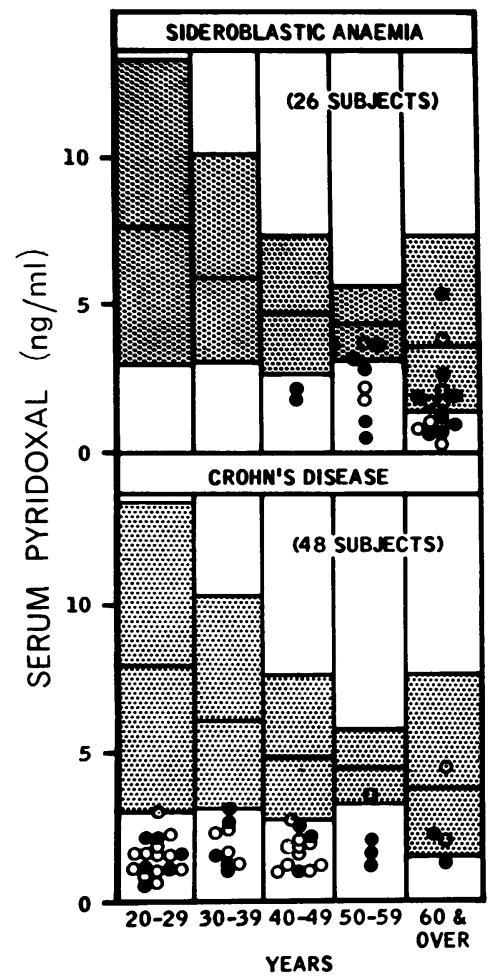

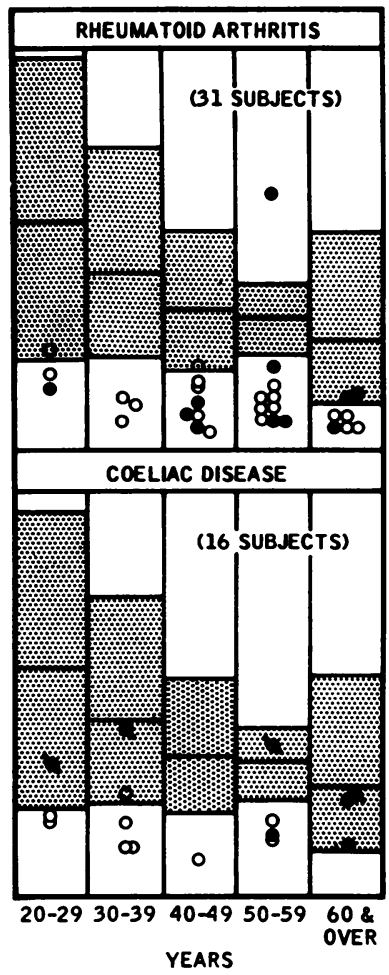

YEARS

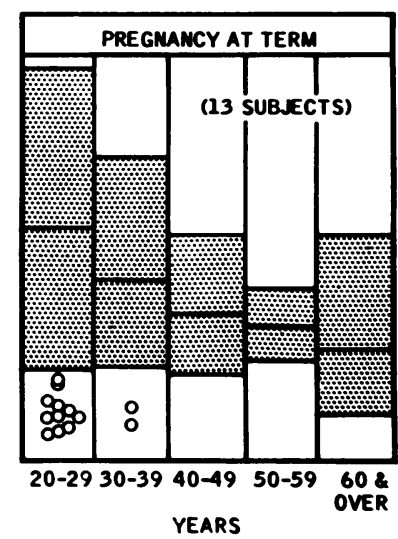

YEARS
Fig. 5 Serum pyridoxal concentrations measured by L. casei microbiological assay in 134 patients with various conditions.

\section{- Men Women}

The hatched areas represent the ranges with means for each age group found in 144 control subjects $(74$ males, 70 females). The plots crossed with lines in coeliac disease represent patients who have been on a gluten-free diet. sensitivity, accuracy, and reproducibility of the method.

The method of maintenance of the organism in disc form (Stamp, 1947; Chanarin et al, 1958) is to be highly recommended in preference to a continuous subculturing method. It is simpler and there is less likelihood of contamination. There was no evidence that the organism was affected if maintained in disc form for up to 20 months.

Pyridoxal, whether in aqueous solution or in serum, remained stable, provided that it was protected from light, and this was a great advantage in the assay of serum $\mathbf{B}_{6}$. It was important not to autoclave pyridoxal solutions with the assay medium, for the presence of amino acids appears to result in the transfer of amino groups to pyridoxal which converts it to pyridoxamine (Snell, 1944). This form of $B_{6}$ does not support growth of $L$. case $i$ at levels normally found in the body. The fact that pyridoxal in serum hydroly- sates deteriorated after storage for six weeks may be due to the contact with amino acids resulting from the hydrolysis of the serum.

The conditions of acid hydrolysis chosen for extraction of free pyridoxal from serum involved ? a smaller amount of serum $(0 \cdot 25 \mathrm{ml})$ than had $\tilde{O}$ been used by others and also a small volume of $\mathrm{N}_{\mathrm{N}}$ acid. The time of autoclaving could also be reduced to one hour, as there was no difference in the assay value when autoclaved at $15 \mathrm{psi}$ over a range of one half to two hours. This is important, for the use of $L$. casei as assay organism for serum pyridoxal (Storvick and Peters, 1964) was invalidated by the production of $\mathrm{D}$-alanine due to a hydrolysis process lasting longer than two hours (Haskell and Wallnöfer, 1967).

Using the present method of hydrolysis to extract serum pyridoxal, the recovery of pyridoxal 8 added to serum was $100 \%$ and assay values were reproducible in spite of a high final dilution of 1 in 200 or 1 in 100 in the assay tube. However, ? 
the conversion of pyridoxal phosphate standards to pyridoxal was not quite complete under these conditions and averaged $87 \%$. Varying the conditions of hydrolysis did not improve this. It might be argued therefore that as pyridoxal phosphate is probably the main form of $B_{6}$ in serum this compound should be used in the standards instead of pyridoxal. However, the present results show that whether pyridoxal or pyridoxal phosphate is used as the standard the difference in the assay values would be very small and would mainly affect the higher serum $\mathbf{B}_{6}$ concentrations.

NATURE OF THE L. casei GROWTH FACTOR IN SERUM

The present observations using Sephadex gel filtration have shown that the $L$. casei growth factor in an acid hydrolysate of serum was eluted in the same position as pyridoxal. Presumably the form of $\mathrm{B}_{6}$ in the hydrolysate is pyridoxal, since it is the only form of $B_{6}$ which promotes growth of $L$. casei at physiological levels. However, the residual growth factor remaining after exposing the eluate to ultraviolet light may not be pyridoxal. On the other hand, a small amount of pyridoxal may have been protected from destruction by ultraviolet light, for this residual factor was slightly greater in the hydrolysate to which large amounts of pyridoxal had been added. In any case the amount was negligible and represented less than $5 \%$ of the total.

In preliminary studies in this laboratory using Streptococcus faecium, which measures both pyridoxal and pyridoxamine (Gregory, 1959), assay values were the same as with $L$. case $i$ which suggests that pyridoxamine is not present in an acid hydrolysate of serum under normal conditions. These observations are consistent with those of Kelsay et al (1968), who could isolate only pyridoxal in acid hydrolysates of whole blood by ion exchange chromatography.

As the present assay results based on acid hydrolysis of serum are similar to those obtained by the majority of enzymatic methods of measuring pyridoxal phosphate in serum or plasma (eg, Table VI), this supports the fact that the naturally occurring form of $B_{6}$ in serum is pyridoxal phosphate and that there are no significant amounts of free pyridoxal.

CLINICAL SIGNIFICANCE OF SERUM

PYRIDOXAL CONCENTRATIONS

\section{Control subjects}

The range of serum pyridoxal concentrations found in control subjects was very similar in terms of free pyridoxal to the ranges found by three other groups of workers who measured plasma pyridoxal phosphate by enzymatic methods (Wachstein et al, 1960; Hamfelt, 1964;
Walsh, 1966) but Hines et al (1969) reported considerably higher values by an enzymat method. Baker, Frank, Ning, Gellene, Hutnerg and Leevy (1966) used the far less sensitive assa organism, Tetrahymena pyriformis, and als obtained higher values.

The present observations have shown that both age and sex affect the serum pyridoxal cor centration. When equal numbers of men and women were grouped together according to age, there was a marked fall in the serum pyridox@l with increasing age and the mean concentrations for corresponding age groups were similar to those reported by Hamfelt (1964). Walsh (1962) also observed a marked fall with increasing age but even earlier Boxer et al (1957) had suggeste this effect of age based on his observation the leucocyte pyridoxal phosphate was higher children than in adults. Furthermore, Rank $\dot{e}_{7}$ Tauber, Horonick, Ranke, Goodhart, and Chois (1960) found increased xanthurenic acid excretion after tryptophan loading and decreased serum GOT levels with increasing age, which disappeared when $B_{6}$ was given.

When the serum pyridoxal concentrations were analysed with regard to sex, the mean co $\overrightarrow{0}$ centrations in men were higher than in womes This was most obvious between the ages of $\dot{20}$ and 40 years, but was not significant after the age of 60 years. It is not possible from our figures to tell whether the difference between sexes persiste until the menopause. Wachstein et al (1960) al observed that the mean plasma pyridoxal phos: phate concentration in women was lower thas that in men, though they made no mention of the age of the subjects.

The explanation for the marked difference in the levels of young men and women is uncertai but could possibly be related to an increased requirement for $\mathbf{B}_{6}$ in women of childbearing age Furthermore, the possible effect of oral contris ceptives has not been investigated in the presen study. ${ }^{1}$ The reason for the fall in the serum pyridoxal with increasing age is also uncertain This has been discussed at length by Hamfert (1964), who mentioned various possibilities, such as defective nutrition, absorption or phosphoryl tion of the vitamin to its active form, or increased urinary loss. Another possibility is a decrease the transport protein to which the compound bound. However, further studies are needed elucidate these observations.

Patients with various conditions

Serum pyridoxal concentrations were measure in sideroblastic anaemia because some patien with this condition have been found to respond treatment with pyridoxine. Sixteen of the patients studied $(62 \%)$ had subnormal levels.

Sideroblastic anaemia has also been reported in rheumatoid arthritis (MacGibbon and Molli $1965)$, and there is other evidence of possible $\overrightarrow{E_{6}}$

'See Addendum. 
deficiency, such as abnormal tryptophan loading tests (Bett, 1962; Flinn, Price, Yess, and Brown, 1964; Pinals, 1964) and decreased excretion of $B_{6}$ compounds in the urine (McKusick, Sherwin, Jones, and Hsu, 1964). The present study provides further evidence of possible $\mathbf{B}_{6}$ deficiency in this condition, in that 30 of the 31 patients $(97 \%)$ had borderline or subnormal serum pyridoxal levels.

Crohn's disease, like rheumatoid arthritis, is an inflammatory disorder. A high incidence of subnormal serum folate levels has already been demonstrated in this condition (Hoffbrand, Stewart, Booth, and Mollin, 1968), and in the present study 44 of the 48 patients studied $(92 \%)$ had borderline or subnormal pyridoxal concentrations. In particular very low levels were found in the young patients.

Sideroblastic anaemia with pyridoxine deficiency has been reported in an adult with coeliac disease, and this completely disappeared when the patient was put on a gluten-free diet (Dawson, Holdsworth, and Pitcher, 1964). Baker and Sobotka (1962) mentioned 'low circulating levels of vitamin $\mathbf{B}_{6}{ }^{\prime}$ in this condition (non-tropical sprue). The tryptophan loading test may also be abnormal in this condition (Kowlessar, Haeffner, and Benson, 1964), and evidence of malabsorption of $B_{6}$ has been reported by Brain and Booth (1964) using tritiated pyridoxine. In this study, 10 of the $12(83 \%)$ untreated patients with coeliac disease had subnormal pyridoxal levels, while four other patients who had been treated with a gluten-free diet all had normal levels.

Finally, pregnant women were studied because low plasma and leucocyte pyridoxal phosphate concentrations were found in the last trimester by Wachstein et al (1960), and abnormal loading tests have also been reported (Wachstein and Gudaitis, 1952; Brown, Thornton, and Price, 1961). Further, Karlin, Croizat, Revol, Pommatau, Viala, and Dumont (1968) showed abnormal pyridoxine load tests in postpartum subjects, using $S$. carlsbergensis to assay serum before and after a dose of pyridoxine. The 13 pregnant women in the present study all had subnormal levels.

The cause of the subnormal serum pyridoxal concentrations in these various conditions is not certain. An increased requirement for $B_{6}$ may be reflected in the low serum levels of the patients with rheumatoid arthritis, Crohn's disease, and in pregnancy, while malabsorption probably played a part in coeliac disease. Furthermore, an inadequate dietary intake of $\mathbf{B}_{6}$ may have been a contributory factor in all these groups. However, the clinical significance of a subnormal serum pyridoxal concentration is still uncertain, but the fact that $B_{6}$-responsive anaemias have been associated with most of these conditions suggests that an alteration in $\mathbf{B}_{6}$ metabolism may occasionally produce serious haematological effects.
This work was supported by a grant to Professor D. L. Mollin from the Wellcome Trust.

We are very grateful to Professor D. L. Mollin and Dr A. H. Waters for their help and advice in the preparation of this paper. We wish to thank Dr A. M. Dawson for allowing us to study his patients with Crohn's disease and coeliac disease, and Dr N. H. Dyer for his collaboration in this study; also $\mathrm{Dr}$ C. J. T. Bateman and Dr K. S. Rodan for providing us with specimens from selected patients from Worthing and Southlands Hospitals. We would also like to thank the physicians of St Bartholomew's, Hammersmith, and West Middlesex Hospitals for allowing us to study patients under their care.

We are indebted to Dr N. G. L. Harding and Dr R. Green who carried out the column chromatography studies on serum hydrolysates, and to Miss Irene Leets for help with the microbiological assays. The Radiochemical Centre, Amersham, kindly provided the tritiated pyridoxine for this study.

\section{References}

Anderson, B. B., and Cowan, J. D. (1968). Effect of light on the Lactobacillus casei microbiological assay. J. clin. Path., 21, 85-87.

Baker, H., Frank, O., Ning, M., Gellene, R. A., Hutner, S. H., and Leevy, C. M. (1966). A protozoological method for detecting clinical vitamin $\mathbf{B}_{6}$ deficiency. Amer. J. clin. Nutr., 18, 123-133.

Baker, H., and Sobotka, H. (1962). Microbiological assay methods for vitamins. Advanc. clin. Chem., 5, 173-235.

Bett, I. M. (1962). Effect of pyridoxine on tryptophan metabolism in rheumatoid arthritis. Ann. rheum. Dis., 21, 388-391.

Boxer, G. E., Pruss, M. P., and Goodhart, R. S. (1957). Pyridoxal5 -phosphoric acid in whole blood and isolated leukocytes of man and animals. J. Nutr., 63, 623-636.

Brain, M. C., and Booth, C. C. (1964). The absorption of tritiumlabslled pyridoxine $\mathbf{H C l}$ in control subjects and in patients with intestinal malabsorption. Gut, 5, 241-247.

Brown, R. R., Thornton, M. J., and Price, J. M. (1961). The effect of vitamin supplementation on the urinary excretion of tryptophan metabolites by pregnant women. J. clin. Irvest., 40, 617-623.

Chanarin, I., Anderson, B. B., and Mollin, D. L. (1958). The absorption of folic acid. Brit. J. Haemat., 4, 156-166.

Dawson, A. M., Holdsworth, C. D., and Pitcher, C. S. (1964). Sideroblastic anaemia in adult coeliac disease. Gut, 5, 304-308.

Flinn, J. H., Price, J. M., Yess, N., and Brown, R. R. (1964). Excretion of tryptophan metabolites by patients with rheumatoid arthritis. Arthr. and Rheum., 7, 201-210.

Gregory, M. E. (1959). The effect of heat on the vitamin $B_{6}$ of milk. J. Dairy Res., 26, 203-220.

Hamfelt, A. (1962). A method of determining pyridoxal phosphate in blood by decarboxylation of L-tyrosine ${ }^{14} \mathrm{C}(\mathrm{U})$. Clin. chim. Acta, 7, 746-748.

Hamfelt, A. (1964). Age variation of vitamin $\mathbf{B}_{6}$ metabolism in man. Clin. chim. Acta, 10, 48-54.

Haskell, B. E., and Wallnōfer, U. (1967). D-alanine interference in microbiological assays of vitamin $\mathbf{B}_{6}$ in human blood. Analyt. Biochem, 19, 569-577.

Hines, J. D., and Love, D. S. (1969). Determination of serum and blood pyridoxal phosphate concentrations with purified rabbit skeletal muscle apophosphorylase b. Lab clin. Med., 73, 343-349.

Hoffbrand, A. V., Stewart, J. S., Booth, C. C., and Mollin, D.L. (1968). Folate deficiency in Crohn's disease: incidence, pathogenesis, and treatment. Brit. med. J., 2, 71-75.

Karlin, R., Croizat, P., Revol, L., Pommatau, E., Viala, J.-J., and Dumont, M. (1968). Recherches sur des carences en vitamine $B_{6}$ pendant la gestation et dans divers états pathologiques à l'aide d'une épreuve de surcharge en pyridoxine. Path. Biol., 16, 917-924.

Kelsay, J., Baysal, A., and Linkswiler, H. (1968). Effect of vitamin $B_{6}$ depletion on the pyridoxal, pyridoxamine and pyridoxine content of the blood and urine of men. J. Nutr., 94, 490-494.

Kowlessar, O. D., Haeffner, L. J., and Benson, G. D. (1964). Abnormal tryptophan metabolism in patients with adult celiac disease, with evidence for deficiency of vitamin $\mathbf{B}_{6}$. J. clin. Invest., 43, 894-903. 
MacGibbon, B. H., and Mollin, D. L. (1965). Sideroblastic anaemia in man: observations on 70 cases. Brit. J. Haemat., 11, 59-69.

McKusick, A. B., Sherwin, R. W., Jones, L. G., and Hsu, J. M. (1964). Urinary excretion of pyridoxine and 4-pyridoxic acid in rheumatoid arthritis. Arthr. and Rheum., 7, 636653.

Pinals, R. S. (1964). Tryptophan metabolism in rheumatic disease. Arthr. and Rheum., 7, 662-669.

Ranke, E., Tauber, S. A., Horonick, A., Ranke, B., Goodhart, R. S., and Chow, B. F. (1960). Vitamin $B_{6}$ deficiency in the aged. J. Geront., 15, 41-44.

Rubin, S. H., Scheiner, J., and Hirschberg, E. (1947). The availability of vitamin $\mathbf{B}_{6}$ in yeast and liver for growth of Saccharomyces carlsbergensis. J. biol. Chem., 167, 599-611.

Snell, E. E. (1944). The vitamin activities of 'pyridoxal' and 'pyridoxamine'. J. biol. Chem., 154, 313-314.

Snell, E. E. (1945). The vitamin $B_{6}$ group. VII. Replacement of vitamin $\mathrm{B}_{6}$ for some microorganisms by $d(-)$-alanine and an unidentified factor from casein. J. biol. Chem., 158, 497-503.

Snell, E. E., and Rannefeld, A. N.(1945). The vitamin B group. $_{6}$ group III. The vitamin activity of pyridoxal and pyridoxamine for various organisms. J. biol. Chem., 157, 475-489.

Stamp, Lord (1947). The preservation of bacteria by drying. $J$. gen. Microbiol., 1, 251-265.

Storvick, C. A., and Peters, J. M. (1964). Methods for the determination of vitamin $\mathbf{B}_{6}$ in biological materials. Vitam. and Horm., 22, 833-854.

Wachstein, M., and Gudaitis, A. (1952). Disturbance of vitamin $B_{6}$ metabolism in pregnancy. J. Lab. clin. Med., 40, 550-557.

Wachstein, M., Kellner, J. D., and Ortiz, J. M. (1960). Pyridoxal phosphate in plasma and leukocytes of normal and pregnant subjects following $B_{6}$ load tests. Proc. Soc. exp. Biol. (N.Y.), 103, 350-353.

Wada, H., Morisue, T., Sakamoto, Y., and Ichihara, K. (1957). Quantitative determination of pyridoxal-phosphate by apotryptophanase of Escherichia coli. J. Vitaminol., 3, 183-188.

Walsh, M. P. (1966). Determination of plasma pyridoxal phosphate with wheat germ glutamic-aspartic apotransaminase. Amer. J. clin. Path., 46, 282-285.

Waters, A. H. (1968). Personal communication.

Waters, A. H., and Mollin, D. L. (1961). Studies on the folic acid activity of human serum. J. clin. Path., 14, 335-344.

\section{Addendum}

Recently Brown, Rose, Price and Wolf (1969) and previously Rose (1966) showed evidence al disturbed $\mathbf{B}_{6}$ metabolism, on the basis of the tryptophan loading test, in subjects taking ant oral contraceptive. We did not specifically que $\overrightarrow{\text { F्ञ }}$ tion our female control subjects about taking oral contraceptives but in view of the above of servations, this cannot be overlooked as a possib reason for the lower serum pyridoxal leves found in young women.

\section{References}

Rose, D. P. (1966). Excretion of xanthurenic acid in the uri⿸广 of women taking progestogen-oestrogen preparation. Nature (Lond.), 210, 196-197.

Brown, R. R., Rose, D. P., Price, J. M., and Wolf, H. (1969). Tryptophan metabolism as affected by anovulatory agen $\}_{\text {. }}$ Ann. N.Y. Acad. Sci., 166, 44. 